\title{
PERAMALAN SUHU UDARA DAN DAMPAKNYA TERHADAP KONSUMSI ENERGI LISTRIK DI KALIMANTAN TIMUR
}

\section{Forecasting of Air Temperature and It's Impact on Electricity Loads in East Kalimantan}

\author{
Lisa Susanti $^{1^{*}}$, Primadina Hasanah $^{2}$, Winarni $^{3}$ \\ ${ }^{1,2}$ Prodi Matematika, Jurusan Matematika dan Teknologi Informasi, Institut Teknologi Kalimantan \\ Jalan Soekarno Hatta No.KM 15 Kota Balikpapan, Kalimantan Timur, Indonesia \\ e-mail:102161017@student.itk.ac.id ; ${ }^{2}$ primadina@lecturer.itk.ac.id; ${ }^{3}$ winarni@lecturer.itk.ac.id ; \\ Corresponding Author*
}

\begin{abstract}
Abstrak
Peningkatan suhu udara akibat perubahan iklim dan pemanasan global telah menjadi perhatian utama bagi pembuat kebijakan, salah satunya adalah pemerintah Kalimantan Timur. Konsumsi energi listrik memiliki hubungan erat dengan perkembangan ekonomi di Kalimantan Timur. Sehingga diperlukan peramalan terhadap suhu udara guna memprediksi konsumsi energi listrik di masa mendatang. Tujuan penelitian ini adalah untuk mengetahui peramalan suhu udara di Kalimantan Timur, yaitu Kota Balikpapan, Samarinda dan Berau serta mengetahui hubungan antara suhu udara dan konsumsi energi listrik di Kalimantan Timur. Dalam penelitian ini, metode yang digunakan adalah metode ARIMA (Autoregressive Integrated Moving Average) dan regresi linear berganda. Hasil analisis menggunakan metode ARIMA diperoleh model terbaik untuk Kota Balikpapan, Samarinda dan Berau secara berturutturut, yaitu ARIMA(1,1,1), $\operatorname{ARIMA}(1,1,1)$ dan $\operatorname{ARIMA}(3,1,0)$. Adapun berdasarkan hasil regresi linear berganda diperoleh nilai $R$-Square sebesar $39 \%$, yang berarti besar pengaruh suhu udara terhadap konsumsi energi listrik, yaitu sebesar 39\%. Dari hasil uji $t$ dan uji $F$, diketahui bahwa suhu udara berpengaruh signifikan terhadap kenaikan konsumsi energi listrik di Kalimantan Timur.
\end{abstract}

Kata Kunci : ARIMA, Listrik, Pemanasan Global, Peramalan, dan Suhu Udara.

\begin{abstract}
The increase in air temperature due to climate change and global warming has become a major concern for policy makers, one of which is the government of East Kalimantan. Electric energy consumption has a close relationship with economic development in East Kalimantan. So it is necessary to forecast the temperature of air in order to predict the consumption of electrical energy in the future. The purpose of this study was to determine the forecasting of air temperatures in East Kalimantan, namely the cities of Balikpapan, Samarinda and Berau and to determine the relationship between air temperature and electricity consumption in East Kalimantan. In this study, the method used is the ARIMA (Autoregressive Integrated Moving Average) and multiple linear regression methods. The results of the analysis using the ARIMA method obtained the best models for the cities of Balikpapan, Samarinda and Berau respectively, namely ARIMA(1,1,1), ARIMA(1,1,1) and ARIMA(3,1,0). Based on the results of multiple linear regression obtained $R$-square value of $39 \%$, which mean that the influence of air temperature on the consumption of electrical energy is 39\%. From the results of the test and $F$ test, it is known that air temperature has a significant effect on the increase in electricity consumption in East Kalimantan.
\end{abstract}

Keywords: air temperature, ARIMA, electricity, forecasting, global warming. 


\section{PENDAHULUAN}

Pemanasan global (global warming) adalah suatu bentuk ketidakseimbangan ekosistem di bumi akibat terjadinya proses peningkatan suhu rata-rata atmosfer, laut dan daratan di bumi. Pemanasan global dapat terjadi karena adanya efek rumah kaca. Emisi gas rumah kaca, khususnya emisi karbon $\left(\mathrm{CO}_{2}\right)$, dapat mengancam terjadinya pemanasan global dan perubahan iklim. Pemanasan global akan menyebabkan penipisan lapisan atmosfir dan meningkatkan suhu bumi [1].

Peningkatan suhu udara akibat perubahan iklim dan pemanasan global telah menjadi perhatian utama bagi pembuat kebijakan, salah satunya Pemerintah Kalimantan Timur. Kenaikan suhu berdampak signifikan pada konsumsi listrik, perluasan jaringan listrik dan rencana tenaga listrik di Kalimantan Timur. Sebagai contoh, pemakaian peralatan pendingin seperti AC maupun peralatan elektronik pendingin lainnya banyak digunakan ketika suhu udara meningkat.

Konsumsi energi listrik memiliki hubungan erat dengan perkembangan ekonomi di Kalimantan Timur. Energi listrik menjadi salah satu faktor penting yang menopang kesejahteraan rakyat [2]. Konsumsi listrik mempercepat pertumbuhan ekonomi, mengurangi ketidaksetaraan, kemiskinan, polusi lingkungan dan konsumsi bahan bakar padat [3]. Proses produksi listrik di Indonesia meliputi generasi (pembangkitan), transmisi (penghantaran) dan distribusi (pembagian). Produksi listrik di Indonesia dikelola oleh Perusahaan Listrik Negara (PLN).

Berdasarkan uraian di atas, dapat disimpulkan bahwa terdapat keterkaitan antara sektor kelistrikan dengan suhu udara. Oleh karena itu, diperlukannya suatu model yang dapat digunakan untuk memprediksi suhu udara di masa yang akan datang secara tepat, cepat dan akurat. Beberapa metode yang dapat digunakan untuk meramalkan suhu udara adalah metode Autoregressive Integrated Moving Average (ARIMA), Arificial Neural Network (ANN) dan Adaptive Neuro Fuzzy Inference System (ANFIS), dan lain-lain. Metode ARIMA mampu memberikan akurasi yang baik untuk peramalan jangka pendek. Peramalan suhu udara dengan metode ARIMA telah dilakukan oleh beberapa pihak antara lain [4] dalam artikel ilmiah dengan penelitian peramalan suhu udara yang dilakukan pada Kota Banda Aceh dengan menggunakan metode ARIMA serta [5] dalam artikel dengan penelitian peramalan temperatur udara pada Kota Surabaya dengan mengggunakan ARIMA. Penelitian terkait dengan perubahan iklim dan listrik telah diteliti dalam [6] yang menganalisis hubungan antara perubahan iklim dan dampaknya terhadap energi listrik dengan menggunakan metode regresi linear di negara bagian, Australia.

Berdasarkan latar belakang masalah di atas, dalam penelitian ini telah dilakukan peramalan suhu udara dengan mengggunakan metode ARIMA. Suhu udara yang diteliti adalah kota-kota di Provinsi Kalimantan Timur, yaitu Samarinda, Balikpapan dan Berau. Menurut Stasiun Badan Meteorologi Klimatologi dan Geofisika (BMKG) Kelas 1 Sultan Aji Muhammad Sulaiman menyatakan bahwa untuk pengukuran suhu udara kota lainnya di Provinsi Kalimantan Timur diukur berdasarkan hasil pengukuran dari stasiun terdekat dengan ketiga kota tersebut. Sedangkan konsumsi energi listrik yang dikaji ialah seluruh konsumsi energi listrik di Kalimantan Timur pada periode Januari 2018 hingga Desember 2018.

Hasil penelitian yang diharapkan yaitu prediksi suhu udara pada periode ke depan yang kemudian disubtitusikan ke dalam persamaan regresi. Hasil model regresi linear akan memberikan informasi prediksi konsumsi energi listrik Kalimantan Timur di masa mendatang.

\section{METODE PENELITIAN}

\subsection{Energi Listrik}

Energi listrik adalah salah satu kebutuhan yang sangat penting dalam kehidupan manusia modern. Serta sebagai Energi listrik merupakan sumber daya ekonomis yang paling utama dibutuhkan dalam berbagai bidang kegiatan. Adapun proses produksi listrik di Indonesia diantaranya pembangkitan, pengantaran dan pembagian. Penyediaan energi listrik di Indonesia dilaksanakan oleh Perusahaan Listrik Negara atau yang biasa disebut PLN [7]. Sesuai dengan UU No. 20 Tahun 2002, PLN merupakan BUMN yang ditunjuk sebagai Pemegang Kuasa Usaha Ketenaga Listrikan (PKUK). PLN bertugas sebagai penyedia listrik di Indonesia. Untuk dapat menyediakan listrik dengan baik, maka PLN wajib menyelenggarakan usahanya secara efesien serta dapat menyediakan listrik sesuai kemampuan rakyat [8]. 


\subsection{Uji Augmented Dickey-Fuller test (ADF)}

Sebelum dilakukan peramalan, perlu dilakukan uji stasioneritas data. Pengujian stasioneritas data dapat dilakukan dengan uji ADF. Persamaan uji stasioner dengan uji ADF adalah sebagai berikut [9].

$$
\Delta Y_{t}=\beta_{1}+\beta_{2} t+\delta Y_{t-1}+\sum_{1=1}^{m} \alpha_{i} \Delta Y_{t-i}+\varepsilon_{t}
$$

dimana $\varepsilon_{t}$ adalah nilai error white noise dan $\Delta Y_{t-i}=\left(Y_{t-1}-Y_{t-2}\right)$. Dalam model ini diperlukan adanya hipotesis. Berikut adalah hipotesis dari uji stasioner data.

$$
\begin{array}{ll}
H_{0}: \delta=0 & \text { (Terdapat unit root, data tidak stasioner) } \\
H_{1}: \delta \neq 0 & \text { (Tidak terdapat unit root, data stasioner) }
\end{array}
$$

Pada uji stasioneritas Augmented Dickey-Fuller, data dikatakan stasioner jika $p$-value $<0,05$ maka hipotesis awal $\left(H_{0}\right)$ ditolak.

\subsection{Model Autoregressive Integrated Moving Average (ARIMA)}

Peramalan ialah suatu proses memperkirakan suatu kejadian di masa mendatang secara sistematik dengan menggunakan informasi dari masa lalu dan sekarang agar kesalahannya dapat diperkecil [10]. Salah satu metode yang dapat digunakan ialah metode ARIMA.

Model ARIMA $(p, d, q)$ dapat dituliskan secara matematis, yaitu sebagai berikut [11].

$$
y_{t}=\mu+\phi_{1} y_{t-1}+\cdots+\phi_{p} y_{t-p}+e_{t}-\theta_{1} e_{t-1}-\cdots-\theta_{q} e_{t-q}
$$

dimana $y_{t}$ adalah nilai variabel $y$ pada waktu $t$. Persamaan (2) dapat dituliskan kedalam notasi backshift.

$$
\begin{array}{ccc}
\left(1-\phi_{1} B-\cdots-\phi_{p} B^{p}\right) & (1-B)^{d} y_{t} & = \\
\operatorname{AR}(p) & \uparrow_{0}+\left(1-\theta_{1} B-. .-\theta_{q} B^{q}\right) \\
\text { difference }(d) & \operatorname{MA}(q)
\end{array}
$$

\subsection{Kriteria Pemilihan Model Terbaik}

Jika dalam peramalan terdapat lebih dari satu parameter yang signifikan terhadap model, maka untuk pemilihan model terbaik dilihat pada nilai AIC dan RMSE terkecil dari model signifikan, dalam hal ini pada data in sample [12].

1. Akaike Info Criterion (AIC)

$$
\operatorname{AIC}(\mathrm{M})=n \ln \hat{\sigma}_{a}^{2}+2 M
$$

dimana :

M : Banyaknya parameter didalam model

$n \quad$ : Jumlah observasi

$\hat{\sigma}_{a}^{2} \quad$ : Varian dari sisa (residual)

\section{Root Mean Square Error (RMSE)}

dimana :

$$
R M S E=\sqrt{\frac{\sum_{t=1}^{n}\left(A_{t}-F_{t}\right)^{2}}{n}}
$$

$A_{t} \quad$ : Data observasi pada waktu $t$

$F_{t} \quad$ : Data hasil peramalan pada waktu $t$

$n \quad$ : Jumlah observasi

\subsection{Ketepatan Metode Peramalan}

Tujuan dilakukannya peramalan ialah untuk menghasilkan ramalan optimum yang tidak memiliki error atau error yang kecil. Jika tingkat kesalahan yang dihasilkan semakin kecil, maka hasil peramalan akan semakin mendekati nilai aktual, dalam hal ini pada data out sample. Menurut [9] untuk menghitung kesalahan prediksi, alat ukur yang digunakan adalah sebagai berikut:

1. Mean Absolute Percentage Error (MAPE)

dimana :

$$
M A P E=\frac{\sum_{t=1}^{n}\left|\frac{A_{t}-F_{t}}{A_{t}}\right|}{n} X 100
$$

$A_{t} \quad$ : Data observasi pada waktu $t$

$F_{t} \quad$ : Data hasil peramalan pada waktu $t$ 
$n \quad$ : Jumlah observasi

\subsection{Analisis Regresi Linear}

Regresi linear digunakan untuk membentuk model atau hubungan antara satu atau lebih variabel bebas $(X)$ dengan variabel terikat $(Y)$. Analisis regresi dengan satu variabel bebas $(X)$ disebut dengan regresi linear sederhana, sedangkan jika terdapat lebih dari satu variabel bebas $(X)$ disebut sebagai regresi linear berganda. Model regresi linear berganda, yaitu [13]:

dimana :

$$
Y=\alpha+\beta_{1} x_{1}+\beta_{2} x_{2}+\cdots+\beta_{k} x_{k}+\varepsilon
$$

\begin{tabular}{|c|c|}
\hline$Y$ & : Variabel terikat \\
\hline$\alpha$ & : Konstanta (nilai $Y$ apabila $x_{1}, x_{2}, \ldots, x_{k}=0$ \\
\hline$\beta_{1}, \beta_{2}, \ldots, \beta_{k}$ & : Koefisien regresi \\
\hline$x_{1}, x_{2}, \ldots, x_{k}$ & Variabel bebas \\
\hline
\end{tabular}

\subsection{Uji Asumsi Klasik}

Suatu model regresi dapat dikatakan sebagai model yang baik jika memenuhi kriteria BLUE (Best Linear Unbias Estimator). Unbias atau tidak bias artinya nilai yang diharapkan sama dengan nilai sebenarnya. BLUE dapat dicapai bila memenuhi Asumsi Klasik [14].

Menurut [15] tujuan pengujian asumsi klasik, yaitu untuk memberikan kepastian bahwa persamaan regresi yang diperoleh memiliki ketepatan dalam estimasi, tidak bias dan konsisten. Adapun asumsi yang harus dipenuhi dalam model regresi antara lain:

1. Uji Multikolinieritas

2. Uji Normalitas

3. Uji Heteroskedastisitas

4. Uji Autokorelasi

Adapun beberapa prosedur penelitian yang dilakukan adalah sebagai berikut.

a. Tahap pertama ialah studi pustaka meliputi: mencari referensi literatur yang berkaitan dengan penelitian melalui buku, jurnal, artikel dan penelitian sebelumnya.

b. Tahap kedua ialah, tahap pengumpulan data dan informasi penelitian. Data yang digunakan adalah data konsumsi listrik dan suhu udara. Data rata-rata harian konsumsi energi listrik didapatkan dari instansi PT. PLN (Persero) Wilayah Kalimantan Timur dengan periode data dimulai dari Januari 2018 sampai Desember 2018. Untuk data peramalan yang digunakan dalam penelitian ini adalah data rata-rata harian suhu udara di Kalimantan Timur yang diukur dari tiga stasiun meteorologi, yaitu stasiun meteorologi Balikpapan, Samarinda dan Berau. Untuk kota lainnya di Provinsi Kalimantan Timur pengukuran suhu udara dilakukan oleh stasiun terdekat dari kota tersebut. Digunakan data suhu udara harian karena pengukuran dilakukan per hari. Periode data suhu udara dimulai dari Januari sampai Desember 2018. Adapun untuk analisis data peramalan periode Januari 2018 sampai November 2018 digunakan sebagai data in sample dan bulan Desember 2018 digunakan sebagai out sample.

c. Tahap ketiga adalah tahap analisis data meliputi: uji stasioneritas data, plot ACF dan PACF, estimasi parameter model, uji residual model, terakhir uji akurasi peramalan. Adapun untuk regresi linear meliputi: regresi linear berganda, uji $t$, uji $F$ dan uji asumsi klasik.

d. Tahap terakhir adalah penarikan kesimpulan.

Alur penelitian ditunjukkan pada Gambar 1, sebagai berikut: 


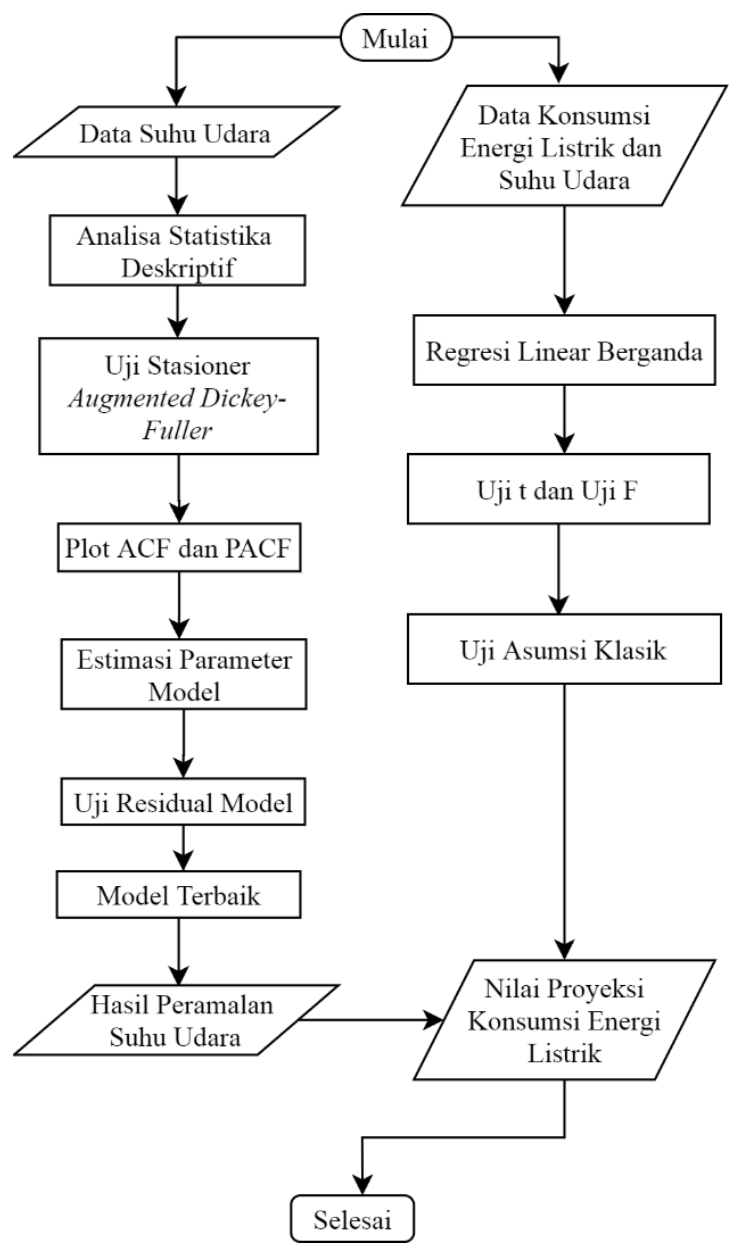

Gambar 1. Alur penelitan

\section{HASIL DAN PEMBAHASAN}

\subsection{Uji Stasioneritas Data}

Data peramalan yang digunakan dalam penelitian ini adalah data rata-rata harian suhu udara di Kalimantan Timur yang diukur dari tiga stasiun meteorologi, yaitu stasiun meteorologi Balikpapan, Samarinda dan Berau. Data dimulai pada Januari 2018 sampai November 2018. Pengolahan data dibantu software $\mathrm{R}$ versi 1.2.5042 Adapun plot data suhu udara pada masing-masing kota ditunjukkan pada gambar berikut:
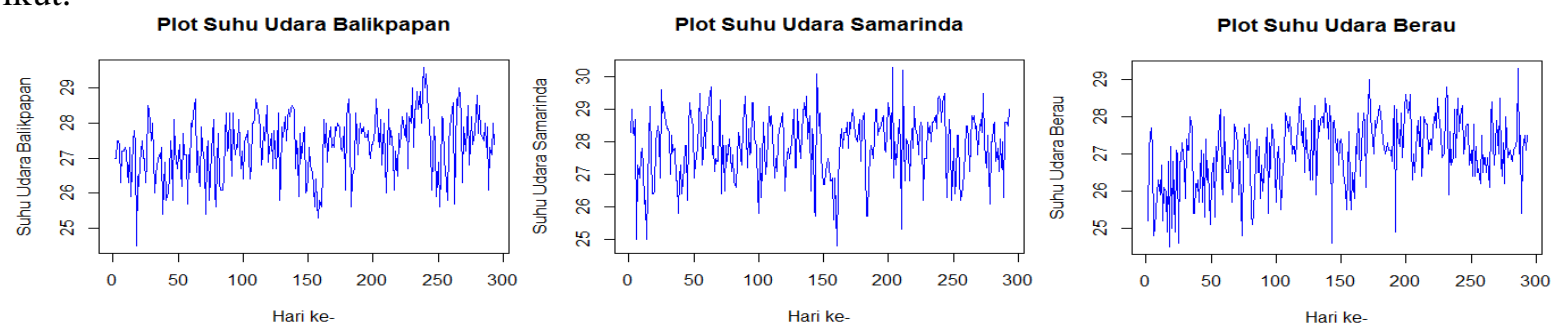

Gambar 2. Plot Data Suhu Udara

Langkah selanjutnya, dilakukan differencing terhadap data suhu udara. Differencing dilakukan agar data memenuhi kondisi stasioner dalam mean. Secara teoritis data stasioner, yaitu nilai mean konstan dan varians konstan, serta kovarians tidak tergantung pada $t$ dan hanya tergantung pada selisih waktu (lag). Setelah dilakukan differencing terhadap masing-masing kota, data lebih stasioner karena nilai mean bernilai nol. Sehingga untuk plot ACF dan PACF menggunakan data setelah differencing. Adapun hasil plot data suhu udara Balikpapan dengan differencing beserta plot ACF dan PACF kota Balikpapan ditunjukkan pada gambar berikut: 

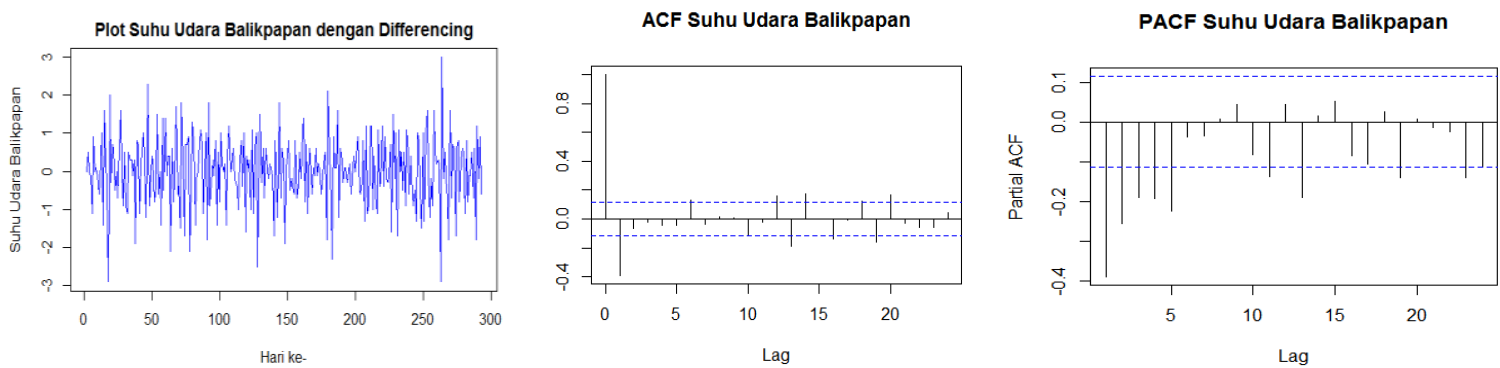

Gambar 3. Plot data, ACF dan PACF Kota Balikpapan

Dari Gambar 3 di atas, dapat dilihat plot ACF cut off pada lag 0 dan 1. Maka model sementara mengandung MA dengan ordo paling tinggi, yaitu MA(1). Sedangkan pada plot PACF model signifikan pada lag 1 sampai lag 3. Maka model mengandung $\mathrm{AR}(1)$, AR(2), dan $\mathrm{AR}(3)$. Karena dilakukan differencing satu kali, maka nilai I ialah satu. Dapat disimpulkan ARIMA $(1,1,1)$ dapat digunakan untuk pendekatan model suhu udara Balikpapan.

Dari gambar plot data diatas, diketahui bahwa data setelah differencing sudah stasioner. Hal ini juga diperjelas dengan uji ADF.

Tabel 1. Uji ADF Suhu Udara Balikpapan

\begin{tabular}{|cccc|}
\hline \multirow{2}{*}{ Augmented Dickey-Fuller } & \multicolumn{1}{c}{ Data } & $\boldsymbol{P}$-Value & Keputusan \\
\cline { 2 - 4 } & $\begin{array}{c}\text { Suhu Balikpapan } \\
\text { differencing }\end{array}$ & 0,01 & Tolak $\left(H_{0}\right)$ \\
\hline
\end{tabular}

Adapun hasil plot data suhu udara Samarinda dengan differencing, plot ACF dan PACF untuk Kota Samarinda ditunjukkan pada Gambar berikut:
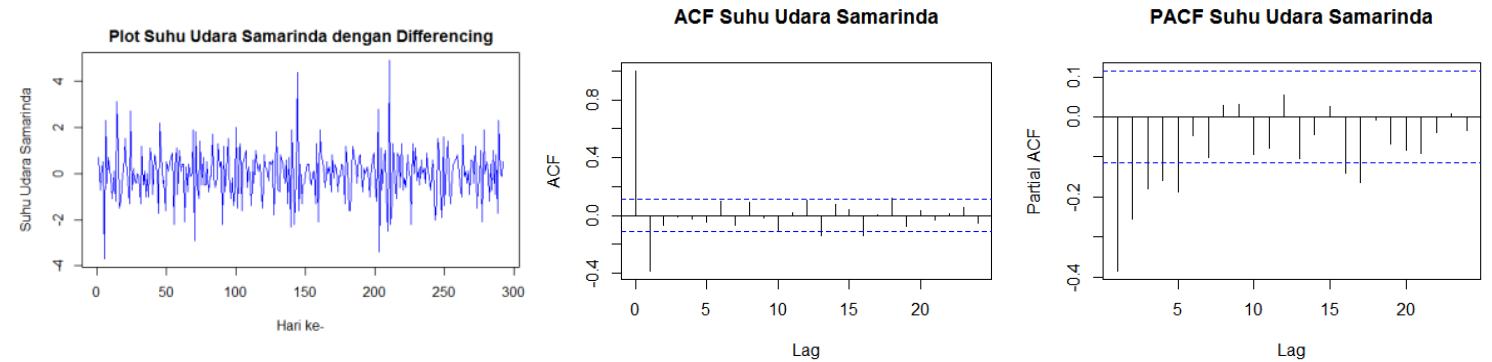

Gambar 4. Plot data, ACF dan PACF kota Samarinda

Dari Gambar 4 di atas, dapat dilihat plot ACF cut off pada lag 0 dan 1. Maka model sementara mengandung MA dengan ordo paling tinggi, yaitu MA(1). Sedangkan pada plot PACF model signifikan pada lag 1 sampai lag 3. Maka model mengandung AR(1), AR(2), dan AR(3). Karena dilakukan differencing satu kali, maka nilai I ialah satu. Dapat disimpulkan ARIMA $(1,1,1)$ dapat digunakan untuk pendekatan model suhu udara Samarinda.

Dari Gambar plot data diatas, diketahui bahwa data setelah differencing sudah stasioner. Hal ini juga diperjelas dengan uji ADF.

Tabel 2. Uji ADF suhu udara Samarinda

\begin{tabular}{|cccc|}
\hline \multirow{2}{*}{ Augmented Dickey-Fuller } & Data & P-Value & Keputusan \\
\cline { 2 - 4 } & $\begin{array}{c}\text { Suhu Samarinda } \\
\text { differencing }\end{array}$ & 0,01 & Tolak $\left(H_{0}\right)$ \\
\hline
\end{tabular}

Hal yang sama juga dilakukan pada data suhu udara Kota Berau. Berikut hasil plot data suhu udara Berau dengan differencing, plot ACF dan PACF ditampilkan pada Gambar 5. 

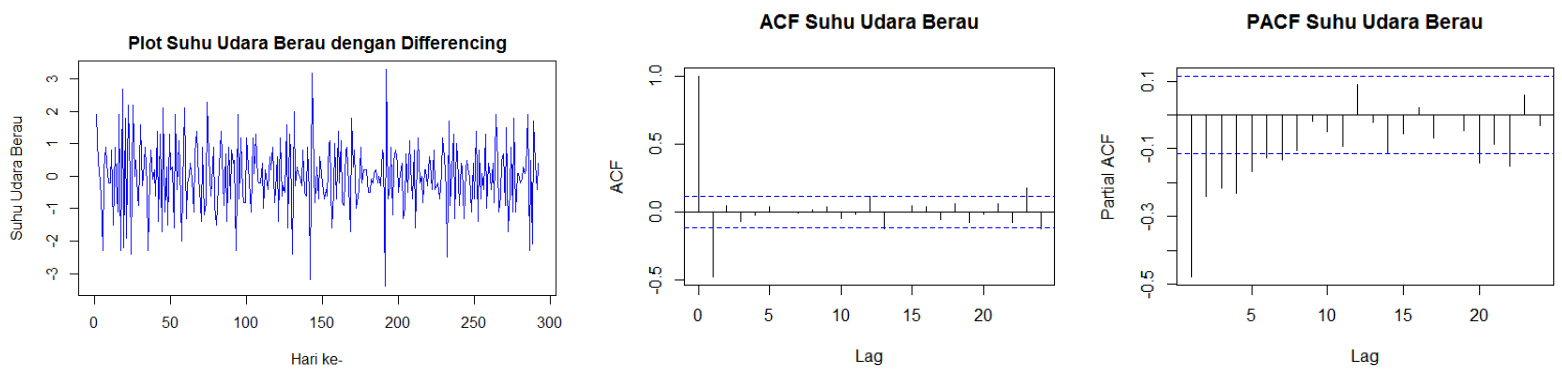

Gambar 5. Plot data, ACF dan PACF kota Berau

Dari Gambar 5 di atas, dapat dilihat bahwa plot ACF cut off pada lag 0 dan 1. Maka model sementara mengandung MA dengan ordo paling tinggi, yaitu MA(1). Sedangkan pada plot PACF model signifikan pada lag 1 sampai lag 3. Maka model mengandung $\operatorname{AR}(1)$, $\operatorname{AR}(2)$, dan $\operatorname{AR}(3)$. Karena dilakukan differencing satu kali, maka nilai I ialah satu.

Setelah dilakukan differencing, data sudah stasioner. Hal ini juga diperjelas dengan uji ADF.

Tabel 3. Tes ADF Suhu Udara Berau

\begin{tabular}{|cccc|}
\hline \multirow{2}{*}{ Augmented Dickey-Fuller } & Data & P-Value & Keputusan \\
\cline { 2 - 4 } & $\begin{array}{l}\text { Suhu Berau } \\
\text { differencing }\end{array}$ & 0,01 & Tolak $\left(H_{0}\right)$ \\
\hline
\end{tabular}

\subsection{Estimasi Parameter Model}

Langkah selanjutnya yaitu menentukan estimasi parameter model. Dipilih model yang signifikan dengan hipotesis:

$H_{0}$ : Parameter $\phi$ dan $\theta=0$ (Parameter tidak signifikan terhadap model)

$H_{1}$ : Parameter $\phi$ dan $\theta \neq 0$ (Parameter signifikan terhadap model)

dengan $\alpha=0,05$ dan $n=294$ hari maka didapatkan statistik uji yaitu:

$$
\begin{aligned}
& t_{\text {tabel }}=t_{0,025 \mid 294}=1,96 \\
& t_{\text {hitung }}=\frac{\text { estimasi parameter }}{\text { standar error parameter }}
\end{aligned}
$$

Pada kriteria uji model dikatakan estimasi parameter signifikan jika $\left|t_{\text {hitung }}\right|>t_{\text {tabel }}$ maka tolak $H_{0}$. Dari hasil rangkuman estimasi parameter model Kota Balikpapan, diketahui parameter model yang signifikan, yaitu $\operatorname{ARIMA}(1,1,0), \operatorname{ARIMA}(1,1,1), \operatorname{ARIMA}(2,1,0)$, dan $\operatorname{ARIMA}(3,1,0)$. Selanjutnya dipilih model dengan nilai AIC dan RMSE terkecil. Berikut tabel hasil overfitting model.

Tabel 4. Hasil overfitting model Balikpapan

\begin{tabular}{ccc}
\hline Model & AIC & RMSE \\
\hline ARIMA(1,1,0) & 747,81 & 0,8630 \\
\hline ARIMA(1,1,1) & 690,9 & 0,7776 \\
\hline ARIMA(2,1,0) & 730,23 & 0,8344 \\
\hline ARIMA(3,1,0) & 721,69 & 0.8193 \\
\hline
\end{tabular}

Berdasarkan Tabel 4, nilai AIC dan RMSE terkecil dimiliki model ARIMA(1,1,1). Sehingga dapat disimpulkan ARIMA $(1,1,1)$ adalah model terbaik untuk meramalkan suhu udara di Balikpapan.

Untuk Kota Samarinda diperoleh estimasi parameter yang signifikan adalah $\operatorname{ARIMA}(1,1,0)$, ARIMA(1,1,1), ARIMA(2,1,0), dan ARIMA(3,1,0). Berikut Tabel hasil overfitting model Samarinda.

Tabel 5. Hasil overfitting model Samarinda

\begin{tabular}{cll}
\hline Model & AIC & RMSE \\
\hline ARIMA(1,1,0) & 848,78 & 1,025 \\
\hline ARIMA $(1,1,1)$ & 784,54 & 0,910 \\
\hline ARIMA $(2,1,0)$ & 831,5 & 0,992 \\
\hline ARIMA $(3,1,0)$ & 823,94 & 0,976 \\
\hline
\end{tabular}


Berdasarkan Tabel 5, nilai AIC dan RMSE terkecil dimiliki model ARIMA(1,1,1). Sehingga dapat disimpulkan ARIMA $(1,1,1)$ adalah model terbaik untuk meramalkan suhu udara di Samarinda.

Kota terakhir ialah Kota Berau, diketahui parameter model yang signifikan, yaitu $\operatorname{ARIMA}(1,1,0)$, $\operatorname{ARIMA}(2,1,0)$ dan ARIMA(3,1,0). Berikut Tabel hasil overfitting model Berau.

Tabel 6. Hasil Overfitting Model Berau

\begin{tabular}{cll}
\hline Model & AIC & RMSE \\
\hline ARIMA(1,1,0) & 794.21 & 0.934 \\
\hline ARIMA $(2,1,0)$ & 777.87 & 0.905 \\
\hline ARIMA $(3,1,0)$ & 764.31 & 0.881 \\
\hline
\end{tabular}

Berdasarkan Tabel 6, diperoleh model $\operatorname{ARIMA}(3,1,0)$ adalah model yang terbaik untuk meramalkan suhu udara di Berau. Hal ini dikarenakan $\operatorname{ARIMA}(3,1,0)$ memiliki nilai AIC dan RMSE terkecil.

\subsection{Uji Residual Model}

Pengujian residual model digunakan untuk memastikan bahwa model layak untuk digunakan peramalan. Uji yang dilakukan ialah uji white noise dan uji kenormalan model. Pengujian white noise umumnya dilakukan untuk mengetahui ke-independenan residual dan homogenitas dari residual. Selanjutnya uji kenormalan nilai residual dari model peramalan juga perlu dilakukan untuk mengetahui nilai residual berdistribusi normal atau tidak.

\subsubsection{Uji Residual Model Balikpapan}

Hasil uji residual ditampilkan pada Gambar 6, berikut:
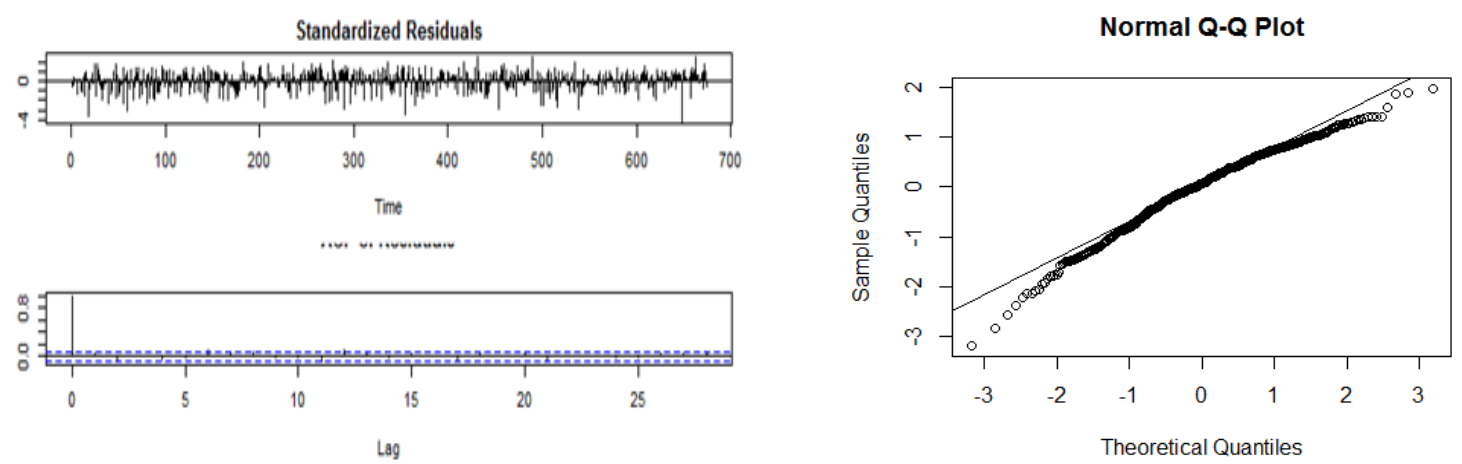

Gambar 6. Uji White Noise dan Normal ARIMA(1,1,1)

Berdasarkan Gambar 6, diketahui bahwa residual model ARIMA $(1,1,1)$ bersifat white noise, hal ini ditunjukkan pada plot ACF terlihat tidak ada yang melewati batas interval pada lag $>0$. Kemudian pada uji normalitas ditunjukkan pada gambar disebelah kanan. Dilihat pada gambar, sebaran residual mendekati garis disepanjang garis diagonal $q-q$ plot tersebut. Maka dapat disimpulkan residual ARIMA $(1,1,1)$ berdistribusi normal.

\subsubsection{Uji Residual Model Samarinda}

Hasil uji residual model Samarinda ditunjukkan pada Gambar 7, berikut.
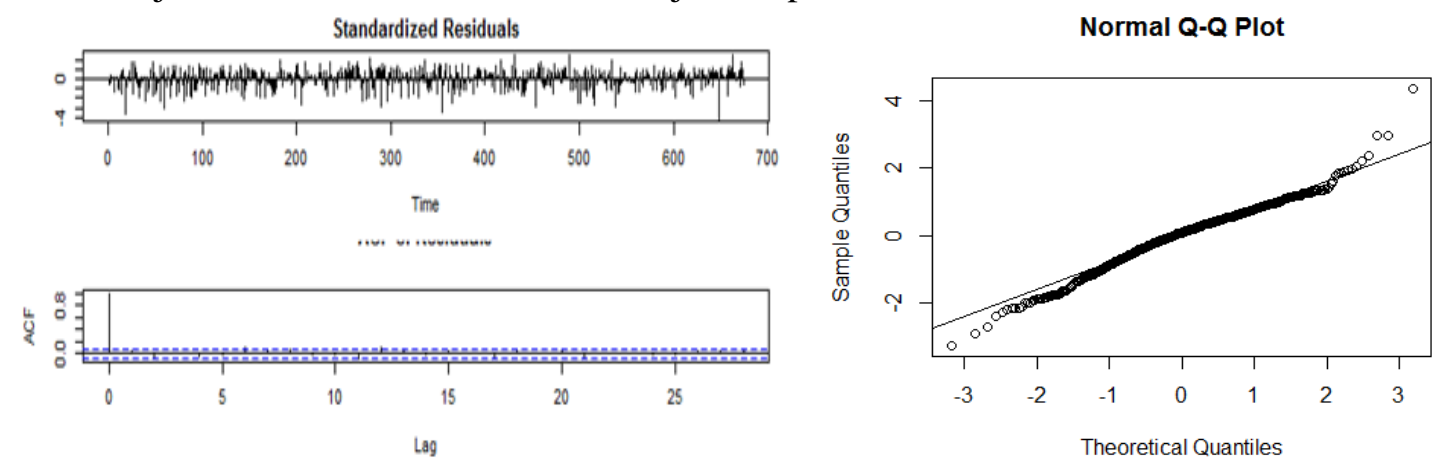

Gambar 7. Uji white noise dan normal ARIMA(1,1,1) 
Berdasarkan Gambar 7, diketahui bahwa residual model ARIMA(1,1,1) pada plot ACF tidak ada yang melewati batas interval pada lag $>0$. Sehingga residual ARIMA $(1,1,1)$ dikatakan bersifat white noise. Selanjutnya pada uji normalitas ditunjukkan pada gambar normal $q-q$ plot. Dilihat pada gambar tersebut, sebaran residual mendekati garis disepanjang garis diagonal $q-q$ plot tersebut. Maka dapat disimpulkan residual ARIMA $(1,1,1)$ berdistribusi normal.

\subsubsection{Uji Residual Model Berau}

Pengujian residual ARIMA(3,1,0) ditampikan pada gambar berikut.
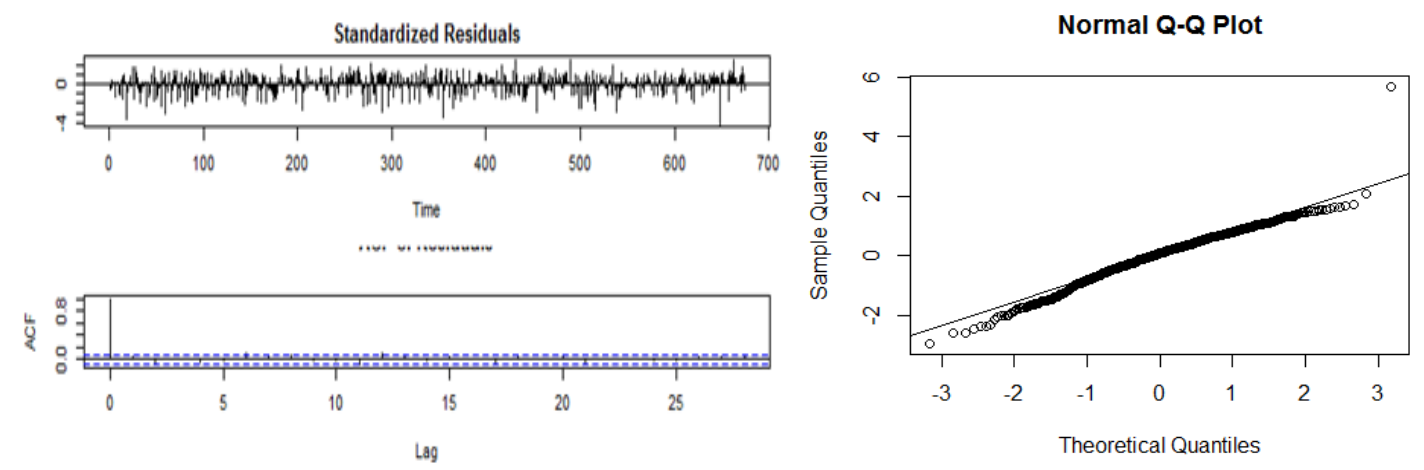

Gambar 8. Uji white noise dan normal ARIMA(3,1,0)

Berdasarkan hasil Gambar 8, diketahui bahwa residual model ARIMA $(3,1,0)$ pada plot ACF tidak ada yang melewati batas interval pada lag $>0$. Maka residual $\operatorname{ARIMA}(3,1,0)$ dikatakan bersifat white noise Selanjutnya pada uji normalitas ditunjukkan pada gambar normal $q-q$ plot. Normalitas ditandai dengan sebaran residual mendekati garis di sepanjang garis diagonal $q-q$ plot. Maka dapat disimpulkan residual $\operatorname{ARIMA}(3,1,0)$ berdistribusi normal.

\subsection{Model Terbaik}

1. Model Terbaik Peramalan Suhu Udara Balikpapan

Setelah dilakukan uji residual model, diperoleh model terbaik peramalan suhu udara Balikpapan adalah model ARIMA $(1,1,1)$. Model ini dapat dituliskan kedalam persamaan matematis sebagai berikut.

$$
y_{t}=1,3374 y_{t-1}-0,3374 y_{t-2}+0,9677 e_{t-1}+e_{t} .
$$

Untuk mengetahui akurasi peramalan dilakukan dengan menghitung error. Nilai error diperoleh dari data lapangan dikurangkan dengan data hasil peramalan. Persen error dari hasil ramalan diperoleh dari nilai MAPE yaitu sebesar $2,11 \%$. Nilai tersebut kurang dari $10<10$, artinya model ARIMA $(1,1,1)$ memiliki tingkat akurasi peramalan yang tinggi.

\section{Model Terbaik Peramalan Suhu Udara Samarinda}

Setelah uji residual model, diperoleh model terbaik peramalan suhu udara Samarinda adalah model $\operatorname{ARIMA}(1,1,1)$. Model ini dapat dituliskan kedalam persamaan matematis sebagai berikut.

$$
y_{t}=1,334 y_{t-1}-0,3341 y_{t-2}+0,9638 e_{t-1}+e_{t} .
$$

Untuk mengetahui akurasi peramalan dilakukan dengan menghitung error. Persen error dari hasil ramalan diperoleh dari nilai MAPE yaitu sebesar 3,02\%. Nilai tersebut masih dibawah $10 \%$, artinya model $\operatorname{ARIMA}(1,1,1)$ memiliki tingkat akurasi peramalan yang tinggi.

\section{Model Terbaik Peramalan Suhu Udara Berau}

Setelah dilakukan estimasi parameter model dan uji residual model, diperoleh model terbaik untuk meramalkan suhu udara Berau adalah model ARIMA(3,1,0). Diperoleh persamaan matematis sebagai berikut.

$$
y_{t}=0,3393 y_{t-1}+0,2727 y_{t-2}+0,1589 y_{t-3}+0,2291 y_{t-4}+e_{t} .
$$

Dengan tingkat akurasi didapatkan dari MAPE sebesar 3,02\%. Nilai inipun masih dibawah $10 \%$. Dapat simpulkan bahwa ARIMA $(3,1,0)$ memiliki tingkat peramalan akurasi yang tinggi. 

berikut.

Adapun plot data in sample dan hasil peramalan dari masing-masing kota ditampilkan pada Gambar
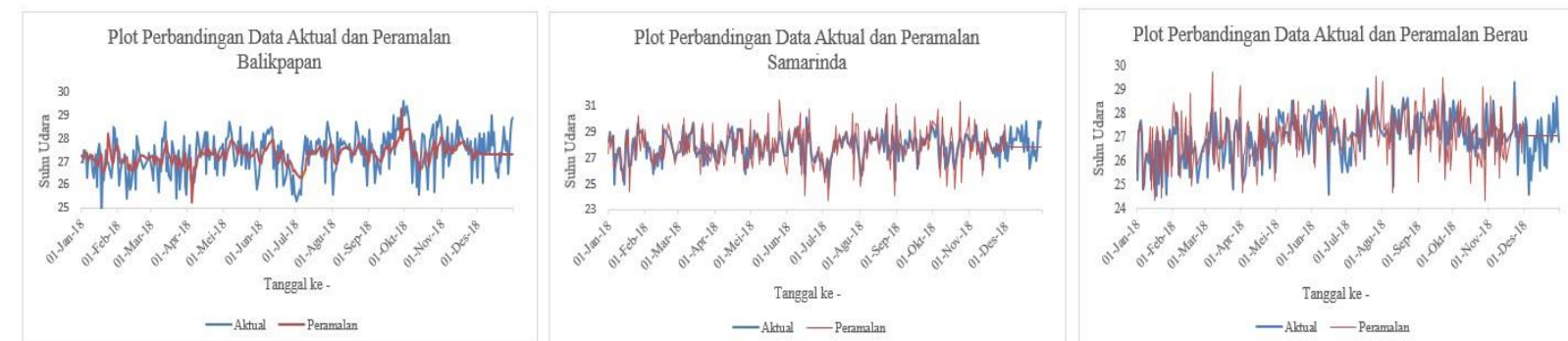

Gambar 9. Plot Perbandingan Data Aktual dan Peramalan Suhu Udara Kalimantan Timur

\subsection{Regresi Linear Berganda}

Pada analisis regresi linear berganda variabel bebas yang digunakan adalah suhu udara Kaltim dan variabel terikat yang digunakan adalah konsumsi energi listrik Kaltim. Data konsumsi energi listrik yang digunakan ialah data harian rata-rata konsumsi energi listrik Kalimantan Timur. Variabel $X_{1}$ (suhu udara Balikpapan), $X_{2}$ (suhu udara Samarinda), $X_{3}$ (suhu udara Berau), dan $Y$ (konsumsi energi listrik). Berikut adalah hasil dari regresi linear berganda.

Tabel 7. Regresi Linear Berganda

\begin{tabular}{ccccccc}
\hline $\begin{array}{c}\text { Model } \\
\text { Regresi }\end{array}$ & $\begin{array}{c}\text { Variabel } \\
\text { Bebas }\end{array}$ & $\begin{array}{c}\text { Variabel } \\
\text { Terikat }\end{array}$ & Coefficient & $\boldsymbol{P}$-value & R-Square & $\begin{array}{c}\text { Analisis } \\
\text { Korelasi }\end{array}$ \\
\hline 1 & Intercept & $Y$ & $-423,429$ & $6,51 \mathrm{e}-12$ & 0,3972 & \\
\hline & $X_{1}$ & & 15,662 & $1,47 \mathrm{e}-10$ & & 0,49 \\
\hline & $X_{2}$ & & 2,375 & 0,256 & & 0,38 \\
\hline & $X_{3}$ & & 11,518 & $5,43 \mathrm{e}-09$ & & 0,32 \\
\hline
\end{tabular}

Berdasarkan Tabel 7, diperoleh persamaan regresi sebagai berikut:

$$
\hat{Y}=-423,429+15,662 X_{1}+2,375 X_{2}+11,518 X_{3}
$$

Interpretasi dari persamaan tersebut adalah sebagai berikut:

a. Konstanta bernilai $-423,429$ menyatakan bahwa apabila nilai suhu udara Balikpapan, Samarinda dan Berau dianggap tidak ada atau sama dengan $0^{\circ} \mathrm{C}$, maka tidak ada kehidupan, sehingga konsumsi energi listrik bernilai negatif. Nilai suhu udara ditiap kota tidak mungkin bernilai $0^{\circ} \mathrm{C}$.

b. Nilai koefiesien regresi untuk variabel suhu udara Balikpapan pada persamaan regresi menunjukkan nilai 15,662 (bernilai positif). Artinya, jika variabel $X_{2}$ (suhu udara Samarinda) dan $X_{3}$ (suhu udara Berau) nilainya tetap dan suhu udara Balikpapan meningkat $1^{\circ} \mathrm{C}$, maka konsumsi energi listrik meningkat sebesar 15,662 MW. Dengan kata lain semakin panas, maka semakin tinggi konsumsi energi listrik.

c. Nilai koefiesien regresi untuk variabel suhu udara Samarinda pada persamaan regresi menunjukkan nilai 2,375 (bernilai positif). Artinya, jika variabel $X_{1}$ (suhu udara Balikpapan) dan $X_{3}$ (suhu udara Berau) nilainya tetap dan suhu udara Samarinda meningkat $1^{\circ} \mathrm{C}$, maka konsumsi energi listrik meningkat sebesar 2,375 MW. Dengan kata lain semakin panas, maka semakin tinggi konsumsi energi listrik.

d. Nilai koefiesien regresi untuk variabel suhu udara Berau pada persamaan regresi menunjukkan nilai 11,518 bernilai positif). Artinya, jika variabel $X_{1}$ (suhu udara Balikpapan) dan $X_{2}$ (suhu udara Samarinda) nilainya tetap suhu udara Berau meningkat $1^{\circ} \mathrm{C}$, maka konsumsi energi listrik meningkat sebesar 11,518 MW. Dengan kata lain semakin panas, maka semakin tinggi konsumsi energi listrik.

Adapun nilai dari $R$-square yang diperoleh pada Tabel diatas adalah 0,39 . Hal ini menunjukkan bahwa pengaruh variabel suhu udara terhadap konsumsi energi listrik secara simultan adalah sebesar 0,39 atau $39 \%$. Sedangkan sisanya $61 \%$ dipengaruhi oleh variabel lainnya.

\subsection{Uji $t$}

Uji $t$ berguna untuk mengetahui pengaruh variabel bebas terhadap variabel terikat secara parsial. Hipotesis yang digunakan dalam uji $t$ ialah $H_{0}$ : Parameter $\rho=0$ (tidak terdapat pengaruh parsial variabel 
bebas terhadap variabel terikat) dan $H_{1}$ : Parameter $\rho \neq 0$ (terdapat pengaruh parsial variabel bebas terhadap variabel terikat). Adapun dasar pengambilan keputusan dalam uji $t$, yaitu gagal tolak $H_{0}$ apabila nilai dari uji $t$-hitung $\leq t$-tabel, sebaliknya jika tolak $H_{0}$ apabila nilai dan $t$-hitung $\geq t$-tabel.

\subsection{Uji $F$}

Uji $F$ berguna untuk mengetahui pengaruh variabel bebas terhadap variabel terikat secara simultan. Hipotesis yang digunakan dalam uji $F$ ialah $H_{0}$ : Parameter $\rho=0$ (tidak terdapat pengaruh simultan variabel bebas terhadap variabel terikat) dan $H_{1}$ : Parameter $\rho \neq 0$ (terdapat pengaruh simultan variabel bebas terhadap variabel terikat). Adapun dasar pengambilan keputusan dalam uji $F$, yaitu gagal tolak $H_{0}$ apabila nilai dari uji F-hitung $\leq F$-tabel, sebaliknya jika tolak $H_{0}$ apabila nilai dan $F$-hitung $\geq F$-tabel. Berikut adalah hasil dari uji $t$ dan uji $F$.

Tabel 8. Uji $t$ dan Uji $F$

\begin{tabular}{|rccccccc|}
\hline $\begin{array}{c}\text { Variabel } \\
\text { Bebas }\end{array}$ & $\begin{array}{c}\text { Variabel } \\
\text { Terikat }\end{array}$ & t-Hitung & t-Tabel & $\begin{array}{c}\text { Keputusan } \\
\text { Uji } \boldsymbol{t}\end{array}$ & F-Hitung & F-Tabel & $\begin{array}{c}\text { Keputusan } \\
\text { Uji } \boldsymbol{F}\end{array}$ \\
\hline $\boldsymbol{X}_{\mathbf{1}}$ & $\boldsymbol{Y}$ & 6,649 & 1,967452 & Tolak $H_{0}$ & 63,48 & 3,024132 & Tolak $H_{0}$ \\
\hline $\boldsymbol{X}_{\mathbf{2}}$ & & 2,087 & & Tolak $H_{0}$ & & & Tolak $H_{0}$ \\
\hline $\boldsymbol{X}_{\mathbf{3}}$ & & 6,015 & & Tolak $H_{0}$ & & & Tolak $H_{0}$ \\
\hline
\end{tabular}

\subsection{Uji Asumsi Klasik}

\section{a. Uji Normalitas}

Uji normalitas bertujuan untuk mengetahui residual berdistribusi normal. Pengujian normalitas menggunakan uji grafis yaitu normal $Q Q$ plot. Berikut hasil uji normalitas ditampilkan pada Gambar berikut.

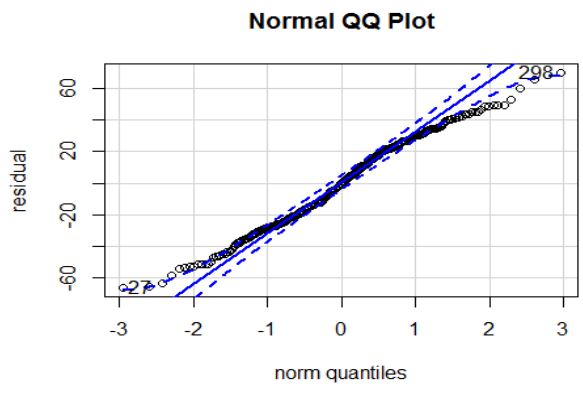

Gambar 10. Uji normalitas residual model regresi

\section{b. Uji Asumsi Klasik}

Berikut uji asumsi klasik untuk multikolinieritas, heteroskedastisitas dan autokorelasi.

Tabel 9. Uji Asumsi Klasik

\begin{tabular}{cccccc}
\hline $\begin{array}{c}\text { Model } \\
\text { Regresi }\end{array}$ & $\begin{array}{c}\text { Variabel } \\
\text { Terikat }\end{array}$ & $\begin{array}{c}\text { Variabel } \\
\text { Bebas }\end{array}$ & $\begin{array}{c}\text { P-value } \\
\text { Heteroskedastisitas }\end{array}$ & $\begin{array}{c}\text { VIF } \\
\text { Multikolinieritas }\end{array}$ & $\begin{array}{c}\text { P-value } \\
\text { Autokorelasi }\end{array}$ \\
\hline 1 & $\boldsymbol{Y}$ & $\boldsymbol{X}_{\mathbf{1}}$ & 0,5503 & 1,690 & $2,2 \mathrm{e}-16$ \\
\hline & & $\boldsymbol{X}_{\mathbf{2}}$ & & 1,665 & \\
\hline & & $\boldsymbol{X}_{3}$ & 1,231 & \\
\hline
\end{tabular}

Berdasarkan Tabel 9, diketahui bahwa untuk uji asumsi klasik pada heteroskedastisitas nilai nilai $p$ value hasil uji heteroskedastisitas model regresi lebih besar dari $a=0,05$. Sehingga dapat diartikan bahwa model regresi tidak terjadi heteroskedastisitas.

Selanjutnya diketahui nilai VIF dari multikolinieritas $X_{1}, X_{2}$ dan $X_{3}$ kurang dari 10, artinya tidak terjadi korelasi yang tinggi antara variabel bebas dalam setiap model regresi. Sehingga dapat disimpulkan bahwa model regresi tidak mengalami masalah multikolinieritas.

Uji asumsi klasik yang terakhir adalah uji autokorelasi. Berdasarkan Tabel 9, nilai $p$-value kurang dari taraf signifikan $a=0,05$. Dengan kata lain, model regresi terdapat masalah autokorelasi. Hal ini tidak memenuhi uji autokorelasi, maka estimator dapat dikatakan hanya linear unbias estimator (LUE). 


\subsection{Nilai Proyeksi Konsumsi Energi Listrik Provinsi Kalimantan Timur}

Proyeksi konsumsi energi listrik diperoleh dari hasil peramalan suhu udara disetiap kota yang sudah didapatkan dari perhitungan di atas, kemudian dimasukkan ke dalam persamaan regresi. Berikut merupakan Tabel proyeksi konsumsi energi listrik pada periode Desember 2018.

Tabel 10. Proyeksi Konsumsi Energi Listrik Kalimantan Timur

\begin{tabular}{cccccc}
\hline Tanggal & $\begin{array}{c}\text { Konsumsi } \\
\text { Energi } \\
\text { Listrik } \\
\text { (MW) }\end{array}$ & Tanggal & $\begin{array}{c}\text { Konsumsi } \\
\text { Energi } \\
\text { Listrik } \\
\text { (MW) }\end{array}$ & Tanggal & $\begin{array}{c}\text { Konsumsi } \\
\text { Energi } \\
\text { Listrik } \\
\text { (MW) }\end{array}$ \\
\hline 1-Des-18 & 362,12 & 11-Des-18 & 362,99 & 23-Des-18 & 362,99 \\
\hline 2-Des-18 & 363,06 & 13-Des-18 & 362,99 & 25-Des-18 & 362,99 \\
\hline 3-Des-18 & 362,48 & 14-Des-18 & 362,99 & 26-Des-18 & 362,99 \\
\hline 4-Des-18 & 363,24 & 15-Des-18 & 362,99 & 27-Des-18 & 362,99 \\
\hline 5-Des-18 & 362,87 & 16-Des-18 & 362,99 & 28-Des-18 & 362,99 \\
\hline 6-Des-18 & 362,99 & 17-Des-18 & 362,99 & 29-Des-18 & 362,99 \\
\hline 7-Des-18 & 362,87 & 18-Des-18 & 362,99 & 30-Des-18 & 362,99 \\
\hline 8-Des-18 & 362,99 & 19-Des-18 & 362,99 & 31-Des-18 & 362,99 \\
\hline 9-Des-18 & 362,99 & 20-Des-18 & 362,99 & & \\
\hline 10-Des-18 & 362,99 & 21-Des-18 & 362,99 & & \\
\hline
\end{tabular}

Adapun nilai MAPE dari proyeksi konsumsi energi listrik adalah sebesar 11,9\%. Nilai ini diantara $10 \%$ sampai 20\%. Hal ini berarti bahwa tingkat akurasi dari peramalan masuk kategori peramalan baik.

\section{KESIMPULAN}

Berdasarkan hasil dan pembahasan di atas, diperoleh kesimpulan sebagai berikut:

1) Model terbaik untuk peramalan suhu udara Balikpapan, Samarinda dan Berau ialah secara berturut-turut $\operatorname{ARIMA}(1,1,1), \operatorname{ARIMA}(1,1,1)$ dan $\operatorname{ARIMA}(3,1,0)$.

2) Hasil peramalan suhu udara dari berbagai kota menunjukkan tingkat akurasi peramalan yang tinggi. Dikarenakan pada nilai MAPE yang dihasilkan kurang dari $10 \%$.

3) Rata-rata kenaikan suhu udara, jika suhu udara meningkat $1^{\circ} \mathrm{C}$, maka konsumsi energi listrik Kalimantan Timur secara umum meningkat sebesar 9,851 MW.

4) Dalam hal proyeksi konsumsi energi listrik, diperoleh nilai MAPE sebesar 11,9\%. Nilai ini berada di antara nilai $10 \%$ sampai $20 \%$. Hal ini berarti bahwa tingkat akurasi dari peramalan masuk kategori peramalan baik.

\section{DAFTAR PUSTAKA}

[1] A. Sugiyono, "Penanggulangan Pemanasan Global di Sektor Penggunaan Energi," J. Sains Teknol. Inf., vol. 7, no. 2, pp. 15-19, 2006.

[2] S. Han, S. Yoo, and S. Kwak, "The role of the four electric power sectors in the Korean national economy: an input - output analysis," Energy Policy, vol. 32, pp. 1531-1543, 2004.

[3] M. Rosadi and A. B. Syamsul, "Faktor-Faktor yang Mempengaruhi Konsumsi Listrik di Indonesia," J. Sains Teknol. Inf., vol. 1, no. 2, pp. 273-286, 2019.

[4] S. Anwar, "Peramalan Suhu Udara Jangka Pendek di Kota Banda Aceh dengan Metode Autoregressive Integrated Moving Average (ARIMA)," J. Res. Gate, vol. 5, no. 1, pp. 6-12, 2017.

[5] A. Machmudin and B. S. S. Ulama, "Peramalan Temperatur Udara di Kota Surabaya dengan Menggunakan ARIMA dan Artificial Neural Network," J. Sains dan Seni ITS, vol. 1, no. 1, 2012.

[6] T. Ahmed, K. M. Muttaqi, and A. P. Agalgaonkar, "Climate change impacts on electricity demand in the State of New South Wales, Australia," Appl. Energy, vol. 98, pp. 376-383, 2012.

[7] T. Timoteus Gultom, "Pemenuhan Sumber Tenaga Listrik Di Indonesia," J. Ilm. Res. Sains, vol. 3, no. 1, 2017.

[8] M. Nizam, "Pembangkit Listrik Terdistribusi (Distributed Generation) Sebagai Upaya Pemenuhan Kebutuhan Energi Listrik di Indonesia," J. Kanika, vol. 7, no. 1, pp. 1-7, 2008.

[9] H. Lutkepohl and M. Kratzig, Applied Time Series Econometrics. New York: Cambridge University Press, 2004. 
[10] R. Fitri, G. Rohman, and S. Mujilahwati, "Sistem Prediksi Jumlah Pengunjung Wisata Wego Kec. Sugio Kab.Lamongan Menggunakan Metode Fuzzy Time Series," JOUTICLA, vol. 3, no. 2, pp. 67-74, 2017.

[11] R. J. Hyndman and G. Athanasopoulos, Forecasting: Principles and Practice. Australia: Monash University, 2018.

[12] L. A. Faizah and setiawan, "Pemodelan Inflasi di Kota Semarang, Yogyakarta, dan Surakarta dengan pendekatan GSTAR,” J. SAINS DAN SENI POMITS, vol. 2, no. 2, 2013.

[13] N. R. Draper, H. Smith, and B. Sumantri, Analisis Regresi Terapan Ed ke-2. Semarang: Gramedia, 1992.

[14] D. N. Gujarati, Basic Econometrics Fourth Edition. U.K: The McGraw Hill Companies, 2004.

[15] I. Ghozali, Aplikasi Analisis Multivariate dengan Program SPSS. Jakarta: Badan Penerbit Universitas Diponegoro, 2011. 
